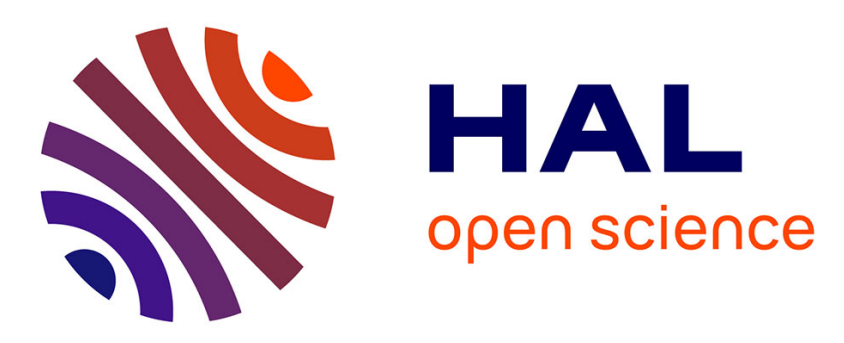

\title{
A Multifunction Antenna: Radar and QPSK Comms
}

Samir Ouedraogo, Israël Hinostroza, Raphaël Gillard, Régis Guinvarc

\section{To cite this version:}

Samir Ouedraogo, Israël Hinostroza, Raphaël Gillard, Régis Guinvarc. A Multifunction Antenna: Radar and QPSK Comms. 2021 IEEE International Conference on Antenna Measurements and Applications, Nov 2021, Antibes Juan-les-Pins, France. hal-03498287

\section{HAL Id: hal-03498287 \\ https://hal.science/hal-03498287}

Submitted on 21 Dec 2021

HAL is a multi-disciplinary open access archive for the deposit and dissemination of scientific research documents, whether they are published or not. The documents may come from teaching and research institutions in France or abroad, or from public or private research centers.
L'archive ouverte pluridisciplinaire HAL, est destinée au dépôt et à la diffusion de documents scientifiques de niveau recherche, publiés ou non, émanant des établissements d'enseignement et de recherche français ou étrangers, des laboratoires publics ou privés. 


\section{A Multifunction Antenna: Radar and QPSK Comms}

\author{
Samir Ouedraogo \\ Université Paris-Saclay, \\ CentraleSupélec, SONDRA \\ Gif-sur-Yvette, France \\ samir.ouedraogo@gmail.com
}

\author{
Israel Hinostroza \\ Université Paris-Saclay, \\ CentraleSupélec, SONDRA \\ Gif-sur-Yvette, France \\ israel.hinostroza@centralesupelec.fr \\ Raphaël Gillard \\ Institut d'Electronique et des \\ Technologies du numéRique, \\ Institut National de Sciences \\ Appliquées \\ Rennes, France \\ raphael.gillard@insa-rennes.fr
}

\author{
Régis Guinvarc'h \\ Université Paris-Saclay, \\ CentraleSupélec, SONDRA \\ Gif-sur-Yvette, France \\ regis.guinvarch@centralesupelec.fr
}

\begin{abstract}
An antenna system for C-band composed of a horn and an independently controlled slotted waveguide using a single source is presented. The radar function is served by the horn antenna and the communication function by the direct modulation on the slots of the feeding waveguide.
\end{abstract}

Keywords-multifunction, radar, communications, direct modulation, horn antenna, slotted waveguide, $C$ band

\section{INTRODUCTION}

In previous works [1] [2], the authors have developed a multifunction antenna using a horn (for the radar function) and a slotted waveguide (for the communication function) with a single source. In this way the comms radiation is in another direction with respect to the radar radiation but also has orthogonal polarization. For the comms function, direct modulation (turning on or off) on the slots was used for a Binary Phase Shift Keying (BPSK) modulation. In this work we extend the possibility to Quadrature Phase Shift Keying (QPSK) direct modulation, which shows how to implement higher PSK modulations.

\section{ANTENNA SYSTEM}

Radar function: we consider a C-band horn antenna: truncated pyramid of height $15.13 \mathrm{~cm}$, base $18.1 \mathrm{~cm} \times 12.6$ $\mathrm{cm}$, top (waveguide feeding) $4.75 \mathrm{~cm} \mathrm{x} 2.2 \mathrm{~cm}$ ([2], Figure 1).

Communication function: we consider a waveguide WR187 , with section $4.75 \mathrm{~cm} \times 2.2 \mathrm{~cm}$. Four slots are etched in the waveguide wall as shown in Figure 1. As explained in [1] [2], slots at same with identical $x$ coordinates but with opposite $y$ coordinates radiate out of phase. To obtain phase quadrature, we add a horizontal displacement corresponding to a quarter wavelength in the waveguide $(\lambda \mathrm{g} / 4)$. In this way, turning on and off each of the slots (one at a time as shown in Figure 2) we can obtain the four phase states needed for QPSK modulation. Generalizing, a combination of vertical and horizontal displacements can be used for higher PSK modulations.

\section{RESULTS FOR RADAR AND QPSK COMMS}

The simulations were done in FEKO and are shown for different cuts at $5 \mathrm{GHz}$ in Figure 2. The radar gain (Theta gain, theta $=90^{\circ}$ ) is $16 \mathrm{~dB}$ and the slot radiations (Phi gain, theta $=$ $0^{\circ}$ ) have a gain of $-0.6 \mathrm{~dB} \pm 0.3 \mathrm{~dB}$ and phases around $0^{\circ}, 90^{\circ}$, $180^{\circ}$ and $270^{\circ} \pm 5.3^{\circ}$. This gives a very low error vector

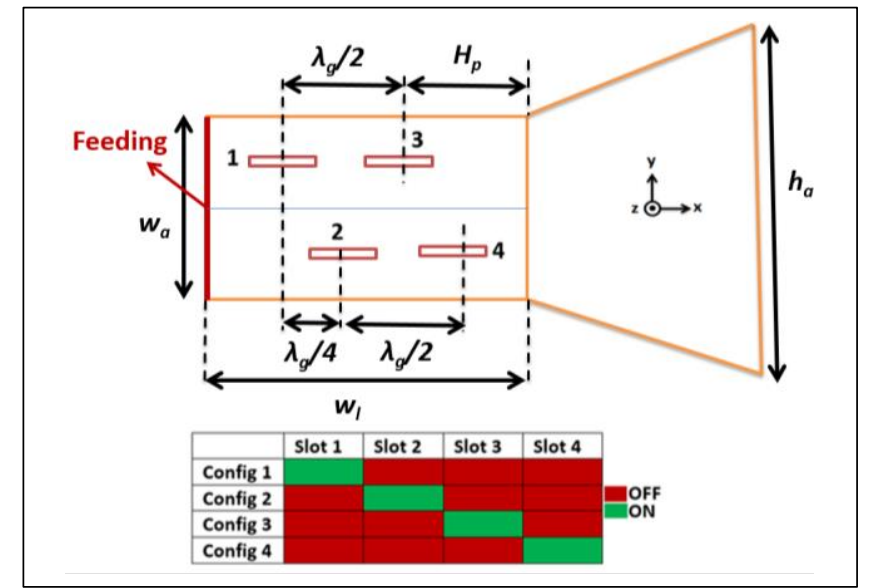

Figure 1: Antenna system configurations and physical characteristics $(w a=4.75 \mathrm{~cm}, w b=2.2 \mathrm{~cm}, w l=13.5 \mathrm{~cm}, \mathrm{hl}=$ $13.5 \mathrm{~cm}, \mathrm{hb}=12.6 \mathrm{~cm}$ and $\mathrm{ha}=18.1 \mathrm{~cm}, d=H p=3.6 \mathrm{~cm})$

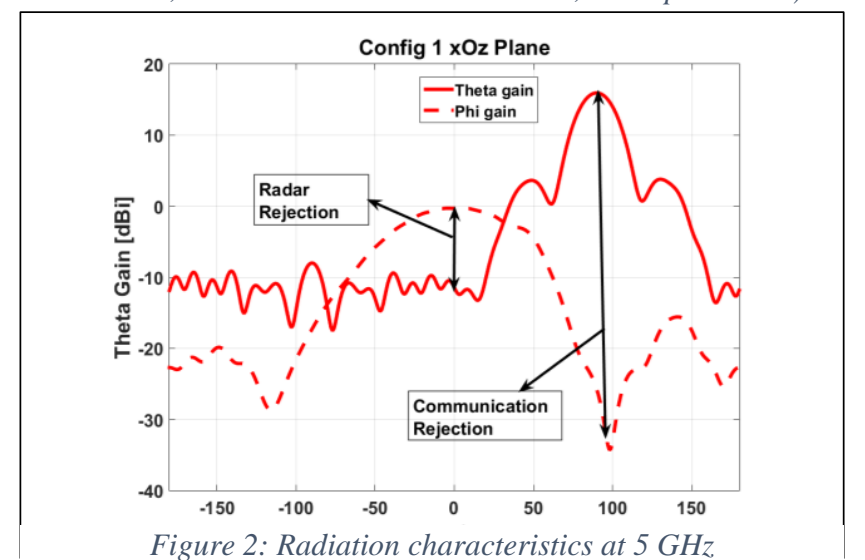

magnitude (EVM, -20 dB). Additionally, as shown in Figure 2 , the communication radiation is below $35 \mathrm{~dB}$ from the radar (comms rejection), and $10 \mathrm{~dB}$ vice versa (radar rejection).

\section{REFERENCES}

[1] S. Ouedraogo, I. D. Hinostroza Sáenz, R. Guinvarc'h, R. Gillard, "Design and Experimental Validation of Multifunction Antenna with Direct Modulation for Radar and Communication," Progress In Electromagnetics Research, Vol. 164, pp. 17-25, 2019. http://www.jpier.org/PIER/pier.php? paper $=18061804$

[2] S. Ouedraogo, I. D. Hinostroza Sáenz, R. Guinvarc’h, R. Gillard, “A multifunction antenna with direct modulation and beam agility," 2017 11th European Conference on Antennas and Propagation (EuCAP), pp. 908-911, 2017. 